DOI https://doi.org/10.30525/978-9934-26-046-9-11

\title{
MULTIFUNCTIONAL RADAR CAPACITY WHILE USING ADAPTIVE CONTROL OF TRACKING MODE PARAMETERS
}

\author{
Nakonechnyi O. A. \\ Candidate of Technical Sciences, Associate Professor \\ Ivan Kozhedub Kharkiv National Air Force University \\ Kharkiv, Ukraine \\ Smirnov O. L. \\ Candidate of Technical Sciences, Associate Professor \\ Ivan Kozhedub Kharkiv National Air Force University \\ Kharkiv, Ukraine \\ Voinov V. V. \\ Candidate of Technical Sciences, Associate Professor \\ Ivan Kozhedub Kharkiv National Air Force University \\ Kharkiv, Ukraine
}

Control of parameters of the multifunctional radar (MF) tracking mode consists in calculating the cycle duration of coordinates measurement of each target $\tau$ and its clock cycle (period for updating information) [1, p. 72]. The relationship between the specified parameters is described by the following expression [2, p. 98]:

$$
\mathrm{T}_{\mathrm{udi}}=\mathrm{N} \cdot \tau,
$$

where $\mathrm{N}$ is the number of simultaneously tracked targets.

To ensure the required tracking accuracy of targets intensively maneuvering throughout the MF radar scanned area, in work [1, p. 74] it is proposed to use the mode control under consideration, which is adaptive to changes in noise levels in the radar measurement channel as well as in the model of the aerial target service dynamics. In this case, the measurement cycle duration (when tracking buddy-type targets) can be expressed as follows

$$
\tau=\tau_{0}+\mathrm{GH}\left[\frac{\Sigma_{\mathrm{rm}}^{2}}{\mathrm{~T}_{\mathrm{udi}}}-\Sigma_{\mathrm{Tp}} \mathrm{G}\right]^{-1},
$$


where $\tau_{0}$ is the unproductive loss of time in the measurement cycle duration, $\mathrm{s}$;

$\mathrm{G}$ is the noise intensity of the target dynamics model, $\mathrm{m}^{2} / \mathrm{s}$;

$\mathrm{H}$ is the measurement noise intensity, $\mathrm{m}^{2} / \mathrm{s}$;

$\Sigma_{\mathrm{rm}}$ is the required magnitude of the variance of the tracked target coordinates estimate, $\mathrm{m}^{2}$.

Simultaneous solution of equations (1) and (2) shows that the measurement cycle duration depends both on the above characteristics of the tracking process as well as on the number of targets served:

$$
\tau=A\left[\sqrt{1-\frac{4 \Sigma_{\mathrm{rm}}{ }^{3} \mathrm{G} \tau_{0}}{\mathrm{~A}^{2} \mathrm{~N}}}-1\right]\left(2 \Sigma_{\mathrm{rm}} \mathrm{G}\right)^{-1},
$$

where the auxiliary function is

$$
\mathrm{A}=\mathrm{GH}-\Sigma_{\mathrm{rm}} \mathrm{G} \tau_{0}-\frac{\Sigma_{\mathrm{rm}}^{2}}{\mathrm{~N}} .
$$

Analysis of expression (3) from the point of view of the physical feasibility of such duration measurement leads to the conclusion that the MF radar capacity under consideration, expressed by the maximum number of simultaneously tracked targets $\mathrm{N}_{\text {мах }}$, is equal to:

$$
\mathrm{N}_{\mathrm{Max}}=\left[\frac{\sqrt{\Sigma_{\mathrm{rm}}^{3} \mathrm{G \tau}_{0}}-\sqrt{\mathrm{D} / 4}}{\mathrm{GH}-\Sigma_{\mathrm{rm}} \mathrm{G} \tau_{0}}\right]^{2},
$$

where the auxiliary function is

$$
\mathrm{D}=4 \Sigma_{\mathrm{rm}}{ }^{3} \mathrm{G} \tau_{0}+4\left(\mathrm{GH}-\Sigma_{\mathrm{rm}} \mathrm{G} \tau_{0}\right) \Sigma_{\mathrm{rm}}{ }^{2} .
$$

Let's consider a number of illustrative examples that make it possible to quantitatively estimate the MF radar capacity while using adaptive control of its tracking mode parameters. We will accept the characteristics of the investigated MF radar and targets located in the area of its coverage similar to work [1, p. 75].

Let the required target tracking accuracy at a distance of $100 \mathrm{~km}$ be achieved with a signal-to-noise ratio equal to $20 \mathrm{~dB}$ [3, p. 281]. Fig. 1 gives the dependence of the maximum number of targets simultaneously served by the MF radar on the specified value of the variance of their coordinates estimate: 


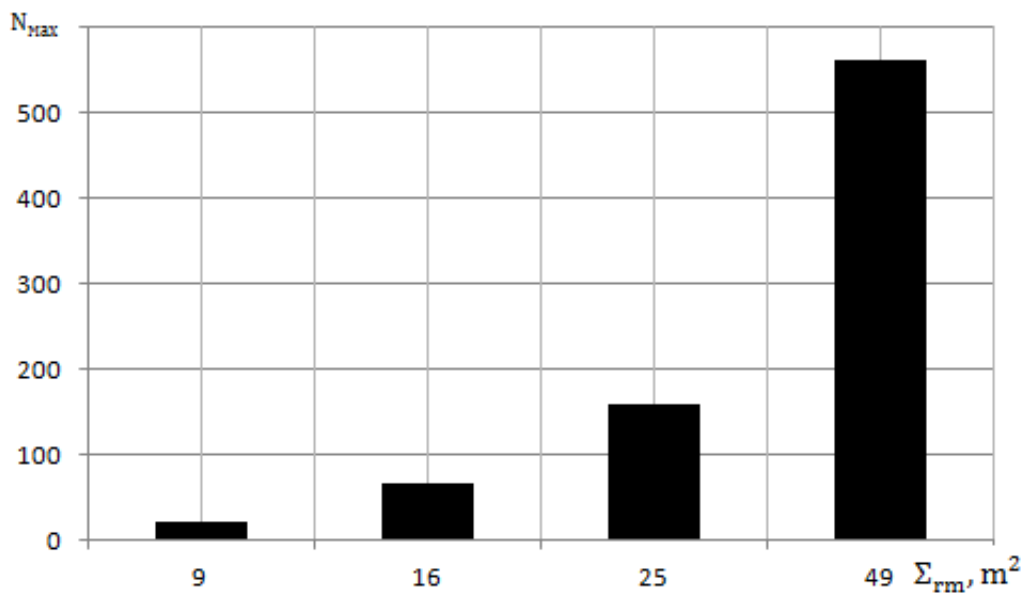

Fig. 1. Dependence of the MF radar capacity on the required target tracking accuracy

Fig. 2 shows the relationship between the MF radar capacity and the amount of available target overload $n$ (for a given tracking accuracy

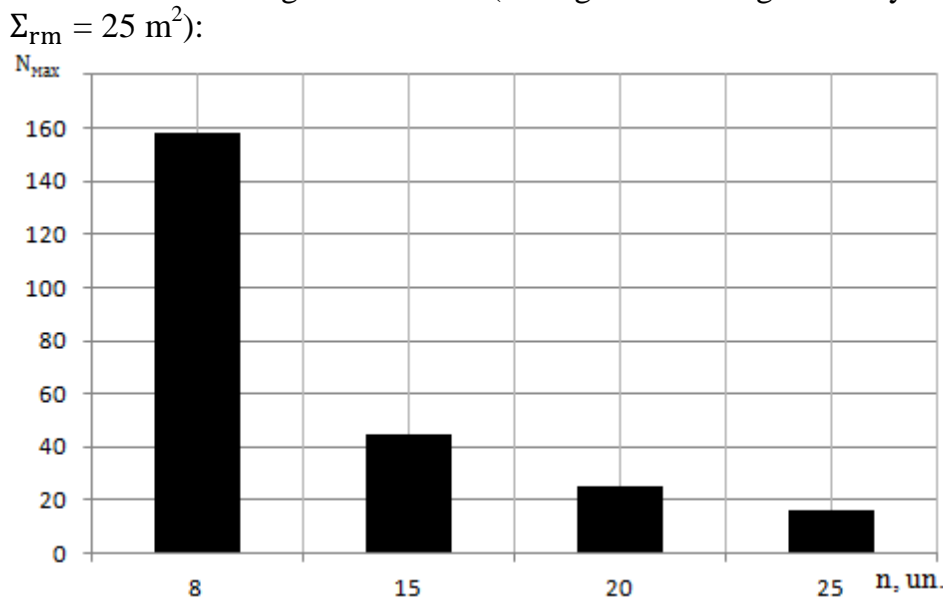

Fig. 2. Dependence of the MF radar capacity on the tracked target maneuvering characteristics

The analysis of the findings presented here shows that adaptive control can provide a significant increase in the MF radar capacity with 50 
a corresponding change in the requirements for the accuracy of the information output or the characteristics of the trajectories of tracked targets.

In other words, for a given tracking accuracy of specific type targets, expressions (1) and (3) describe the parameters of the considered mode of the MF radar subject to this proviso

$$
\mathrm{N} \leq \mathrm{N}_{\text {Max }},
$$

otherwise, it is necessary to reduce the number of simultaneously serviced objects in accordance, for instance, with the priority range of dangerous targets adopted in the radar control algorithm [4, p. 179].

A similar process for the fulfillment of inequation (5) occurs with an increase in the intensity of the tracked targets maneuver.

\section{References:}

1. Адаптивное управление параметрами режима сопровождения многофункциональной РЛС / О.Л. Смирнов, О.Н. Ставицкий, А.А. Наконечный // Наука і техніка Повітряних Сил Збройних Сил України. - 2017. - №. 1(26). -С. 71-77.

2. Синтез многофункционального радиолокатора / Ю.М. Бабкин, В.А. Балагуровский. - М.: МЭИ, 2006. - 108 с.

3. Динамическое проектирование систем управления автоматических манёвренных летательных аппаратов: Учеб. Пособие для студентов втузов / Е.А. Федосов, В.Т. Бобронников, М.Н. Красильщиков, В.И. Кухтенко и др.; Под ред. Е.А. Федосова. - М.: Машиностроение, 1997. $-336 \mathrm{c}$.

4. Система автоматизированного формирования облика зенитных ракетных комплексов / Л.В. Вишнякова, В.И. Кухтенко // Техническая кибернетика. - 1993. - № 6. - С. 137-185. 